\title{
REWETTING DESIGN FOR TROPICAL PEATLAND RESTORATION
}

\author{
${ }^{1}$ Ainun Hasanah, ${ }^{2}$ Muhammad Farouk Setiawan \\ ${ }^{1}$ Urban and Rural Planning Department, Northeast Forestry University, Harbin, China \\ ${ }^{2}$ Mechanical Engineering Department, University of Lambung Mangkurat, Banjarmasin, Indonesia \\ Iainunhasanah2013@yahoo.com, 22mfarouksetiawan@gmail.com
}

\begin{abstract}
Peatlands located in tropical climates are estimated to have an area of $11 \%$ of the total peatland on earth. The scope of tropical peatland is proportional to the significant role this ecosystem plays in the stability of the earth and everything in it. Various efforts have been made to restore the condition of the peatland ecosystem, especially in tropical areas that have been affected by human activities. This study using the literature review method attempts to collect and summarize various peatland restoration efforts carried out in various countries in the world, then serves as a reference and basis for consideration in redesigning peat rewetting infrastructure. The result of this study is a canal blocking design using a PVC pipe filled with peat soil in its cavity. The layout of this PVC pipe canal blocking is designed by considering various factors. Challenges and prospects related to the idea of this canal blocking with PVC pipe were also taken into consideration in the design. It is hoped that the innovation of canal blocking materials can increase resource efficiency and fund for canal blocking construction while maintaining its function and development objectives.
\end{abstract}

Keywords: peatland rewetting design, canal blocking, PVC pipe

DOI: $10.33541 /$ sp.v21i3.2245

Sociae Polites : Majalah Ilmiah Sosial Politik

Faculty of Social and Political Science, Universitas Kristen Indonesia

ISSN 1410-3745 print/ ISSN 2620-4975 online

Volume 21, Number 2 (Youth Peatland Conference)

Pages 111-125 


\section{Introduction}

\subsection{Background}

Peat soil is formed through a very long process because it is an accumulation of dead plants after the slow process of decomposition, then creates a type of soil which containing 80-100\% organic material with several meters thickness (Craft, 2016). Peatland is one type of wetland that has an essential role in the earth and everything in it. The critical role of peatlands, among others: to mitigate floods and soil erosion, to store and filter water, to store carbon, to maintain biodiversity because it is a home for various types of animals and plants, provides drinking water and food sources, and even has a role in mitigation and adaptation to climate change. The importance of peatlands has been recognized by many parties, including the United Nations, which through the UN Environment Action, initiated the Global Peatlands Initiative to protect peatlands by building cooperation with various countries in the world.

The area of peatlands is only $3 \%$ of the total surface area of the earth. However, about $15 \%$ of the total area of peatland scattered around the world has experienced drought (UN Environment, 2019). The drying up of peatlands is the result of massive exploitation, conversion of peatlands for other purposes, such as unsustainable agriculture, plantation and mining, and burning of peatlands. In the end, the peatlands that should bring many benefits, because the conditions are dry and flammable are a source of new problems. One of the problems caused by burning peatlands is the release of carbon dioxide, other greenhouse gases, and even mercury in large amounts, which in turn can accelerate global warming and harm human health (Government of Canada, 2020). Besides, forest fires that occur on peatlands also threaten biodiversity because they have a negative impact on the animals and plants that live in it. Therefore, various efforts are needed to conserve peatlands, one of which is through restoration efforts and the use of technology that can support the sustainability of peatlands.

Figure 1. Peatland Area in Central Kalimantan, Indonesia
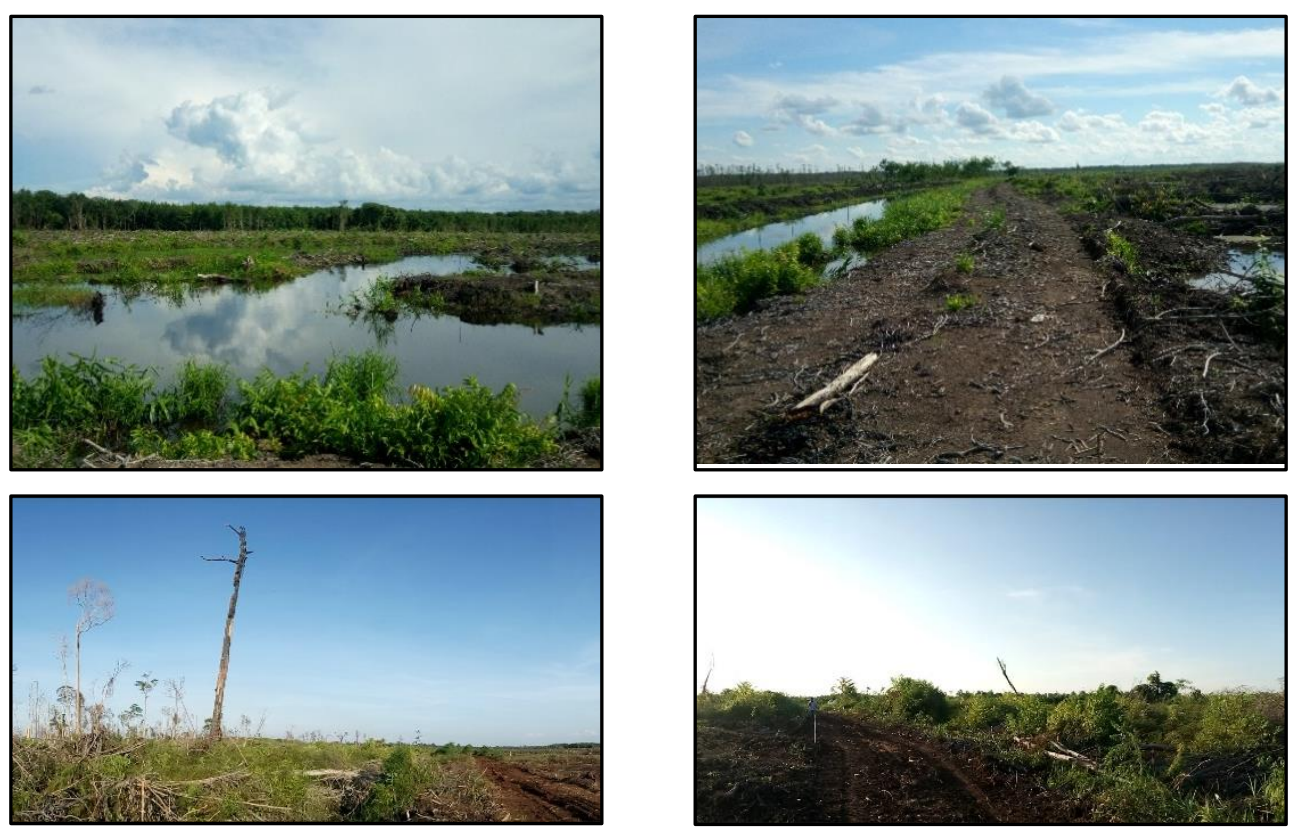

(Source: Author's Documentation, 2016) 
The tropical region, as one of the distribution places of peatlands in the world, has received particular attention due to its unique climatic conditions and characteristics. This study attempts to discuss more deeply the design that can be used to support peatland restoration efforts, especially those in tropical regions. This study also addressed peatland restoration efforts in many countries as the inspiration for the design. It is hoped that the existence of new ideas related to peatland restoration strategy can be taken into account by the authorities, become part of the enrichment of science and technology, and are expected to give benefit to the communities around the peatland area. The use and application of this idea in maintaining the condition of peatlands are expected to be a solution for the problems related to the threat of peatland fires (forest fires) in tropical regions.

\subsection{Research Question}

The research questions in this study are as follows:

1. What are the efforts to rewet and prevent peatland fires in the tropics?

2. What are the challenges and prospects of rewetting design in tropical peatlands?

\subsection{Purpose and Objective}

The objectives of this study are as follows:

1. To understand about rewetting efforts and prevention of peatland fires in the tropics.

2. To understand the challenges and prospects of rewetting design in tropical peatlands.

\section{Literature Review}

\subsection{Tropical Peatland}

Tropical regions are areas that are located in the middle of the earth, which is the area around the equator. The area with a tropical climate is $36 \%$ of the total land area and is inhabited by around 33\% of the world's population (National Geographic, 2011). The characteristics of a tropical climate, including stable-warm temperature throughout the year (25-28 degrees), get more sunshine, has two seasons (summer and rainy), variations in rainfall and precipitation, is home to typical plants and animals that live in the tropical region. Tropical areas are one of the essential sites that play a role in maintaining the stability of the earth and everything in it, mainly because of the existence of biodiversity and the unique ecosystems that exist in the region.

Tropical areas of the earth are also where peatlands are found. The unique characteristics of the tropical climate influence the condition and features of the peatlands in the area, which are known as tropical peatlands. By definition, tropical peat is a type of peat soil found in tropical regions, such as Africa, Southeast Asia, Central, and South America. The tropical peatland is estimated at $11 \%$ of the total peatland area in the world or about $441,025 \mathrm{~km} 2$. In detail, the distribution of tropical peatland located in Southeast Asia, South America, Africa, Central America-the Caribbean, Mainland Asia, and Australia-the Pacific, respectively: 56\%, 24\%, 13\%, 5\%, 1\%, and $<1 \%$ (Rieley and Page, 2016).

Tropical peatland is a sensitive area and is significantly affected by human activities in the area. The existence of deforestation, conversion of land use to industrial plantations, drainage problems, forest fires, the impact of socio-economic factors, and policies are some of the factors that cause peat degradation (Dohong, Aziz and Dargusch, 2017). Also, the effects of climate change that affect tropical peatlands include temperature changes (increasing temperature on earth), changes in rainfall and atmospheric composition, as well as high levels 
of fire and haze (Leng, Ahmed, and Jalloh, 2019). The impact of climate change affects tropical peatlands, and conversely, the problems that occur in tropical peatlands also contribute to exacerbating climate change. The risks and issues faced by tropical peat are a common problem that can have a negative impact on the entire human population on earth.

Apart from the risks and problems that occur in tropical peatlands, there are always opportunities for communities and authorities to repair and prevent damage to tropical peatlands. Efforts to protect tropical peatlands can be carried out by various parties from the government to community scales, from the most straightforward actions such as planting vegetation as well as efforts from the aspects of policies and regulations. These efforts are expected to provide new hope for the existence and sustainability of tropical peatlands on earth, amidst the threat of land-use change and massive exploitation of this critical area.

\subsection{Peatland Restoration Efforts}

Peat restoration is an effort to restore the peat ecosystem so that the water condition of the peatland is maintained. For this reason, efforts are made to rewet the dry peat material due to the lowering of the peat water table. Some of the techniques that can be used to maintain groundwater conditions on peatlands to keep them hydrated are canal blocking, canal piling, and drilling.

a. Canal Blocking

Canal blocking is designed with one or many layers of bulkheads with materials such as wood, plastic, or concrete. The filler of the canal bulkhead itself is mineral/clay, mature peat, and sand.

b. Canal Piling

The filling of the canals here aims to increase sedimentation and reduce drainage. The design of the canal filling is a portion of the canal segment of about 100-200 meters is covered either with deadwood debris, deadwood branches/branches, soil from the canal embankment.

c. Drilling/Borehole

A simple borehole is designed to wet peat during the dry season and functions for wetting/extinguishing and for monitoring the water level in the peat water soil.

Several steps that can be taken in peatland restoration efforts are preceded by planning, which includes a site survey, analyzing survey data, and a recovery plan and preparation for restoration. The location survey stage aims to map the location of the area to be restored by considering various aspects and the effectiveness to be achieved in the restoration planning. In addition, the initial stages in restoration also involve multiple parties from the government to local communities as restoration actors, determining the types of restoration efforts to be implemented, determining the implementation time, and the amount of budget required.

The implementation stages are carried out, namely restoration of hydrological functions and rehabilitation of vegetation (Revegetation). Revegetation, as a form of restoration, requires further research and studies related to the types and characteristics of vegetation suitable for peatlands in specific climatic locations. In the revegetation process, it is generally necessary to have donor and recipient locations, where vegetation from donor sites that meet the criteria is transferred to be planted at the recipient location (restoration site). This revegetation effort is a long-term program and requires a long time for the planted vegetation to grow and develop well in the restoration site, which in turn improves the peat ecosystem.

The next stage is the monitoring and reporting stage, namely in the form of monitoring the location, methods, and techniques applied to evaluate its success as a final report, which can then be used as a basis for future program development. Besides, the implementation of 
peatland restoration efforts requires the participation of various parties, from the central government, regional governments to local communities. Peatlands that are located not far from community settlements are generally a source of livelihood and very close to local community activities. Therefore, the success of the peatland restoration program also requires support from parties at the local level, such as the local village community. In addition to infrastructure development, awareness of the importance of the community's role in peat restoration efforts makes empowerment programs for local communities also needed, namely by increasing the standard of living and economic level of local communities (Pantau Gambut, 2020).

\subsection{Peatland Restoration Efforts in Some Countries}

Peatland restoration efforts have been carried out in various countries around the world. Peatland restoration in various locations, of course, also brings different variations and characteristics of restoration methods. This section tries to summarize the various restoration efforts that have been carried out in many countries as lessons learned, which are expected to inspire related parties to support the efforts to restore peatlands in tropical regions. Countries that have made peatland restoration efforts, including:

a. Canada

Canada uses a technique called The Moss Layer Transfer Technique (MLTT), which aims to restore peatlands by rewetting (with hydrological management), developing and replanting species of peatland plants. The stages carried out in the technique developed by The Peatland Ecology Research Group (PERG) include the planning stage, preparation of the area to be restored, a collection of plant material from the donor area, spreading and planting of plants in the receiving area, spreading mulch, fertilization, rewetting of peatlands by blocking drainage systems, as well as monitoring the restored locations (Quinty, LeBlanc and Rochefort, 2020).

b. China

Restoration efforts in China are carried out in several ways, including blocking drainage canals and gullies (using tractors, peat soil or sand, wooden planks, boulders, and bags), replanting or Revegetation, and damming the restored location by leveling the ground and prevent erosion. These restoration activities are supported by the Chinese government, the United Nations Environment Program, and the European Union (FAO, 2015).

c. European Countries

The European continent also has areas of peatlands that need to be restored. There are various efforts that have been made to restore peatlands in various countries in Europe, including: United Kingdom (increasing cooperation between the public, private and community sectors in restoring 3 types of peatlands in the UK, namely blanket bog, fen, and raised bog); Germany (rewetting and cultivating or managing agricultural land based on peatlands called paludiculture, namely by planting Sphagnum moss); Poland (conducts agriculture-based peatland conservation and hydrological management for the purpose of maintaining biodiversity, and utilizing biomass from peatlands as fuel); Sweden (restoring the hydrological function of the restored area by adjusting the season conditions and monitoring the existing vegetation on site); Ireland (restoration efforts are carried out by blocking drainage, installing dams, and building cooperation with local communities and stakeholders to restore peatlands); and Belarus (doing paludiculture and utilizing peatlands as an alternative or renewable energy source) (Cris, et al., 2014). 
d. Indonesia

Peatland restoration efforts in Indonesia are carried out by the Peat Restoration Agency (BRG) by applying the 3R approach, namely Rewetting (rewetting peatlands), Revegetation (replanting vegetation), and Revitalizing (improving the livelihoods of local communities) (Pantau Gambut, 2020). The program carried out by BRG involved many parties, including the central government, local governments, the private sector, academics, and public participation. Some of the programs that are quite popular recently are canal blocking projects and boreholes for rewetting peat and improving the economy of communities in various parts of Indonesia, such as Kalimantan and Sumatra (Mongabay, 2020).

e. Russia

Peatland management in Russia is carried out with a Decision Support System (DSS), which focuses on rewetting peatlands to reduce GHG emissions and land fires, nature conservation, and the production sector (agriculture, forestry, paludiculture, and peat extraction) (Joosten, Tapio-Biström and Tol, 2012).

f. Africa

Peat restoration programs are also carried out in various countries in Africa. The countries that have carried out these restoration efforts include South Africa and Rwanda. South Africa has carried out five main programs, namely rehabilitation and conservation of wetlands, one of which is rewetting, partnership, increasing public awareness through socialization and education, capacity building, research, and planning. Rwanda has carried out rewetting site, improve local communities roles on cultivation within the marsh, and strengthen partnerships at the planning and implementation stages) (Cris et al., 2014). In addition, the existence of tropical peatlands in the Congo Basin has also made peatland restoration efforts in the African region even more intense because the area of this peatland reaches 145,500 $\mathrm{km}^{2}$ and is estimated to be the most extensive tropical peatland complex (Dargie et al., 2019).

g. Australia

Forest fires that occurred in the Australian continent have increased the need for restoration. Efforts made related to peat restoration in Australia include: improving the hydrological function of the site, regenerating the vegetation complex by planting Sphagnum sp., monitoring and research about various restoration techniques, providing education related to ecological restoration, and installing dams in waterways to forming a surface pond (Cris et al., 2014).

\section{Research Methods}

This study uses a literature review method to gather a variety of important information related to the topic being reviewed. Literature is collected from various sources, such as scientific articles, credible news sources, program reports, as well as the websites of institutions engaged in peatland and its restoration. The various literature collected is then summarized and grouped according to their categories, including by country and region. Literature that specifically discusses tropical peatlands is also used as references in this study. The summary of the results obtained is then used as a basis and consideration in designing technologies and programs that support peatland restoration in tropical regions. The ideas received are the results of studies from various literary sources and lessons-learned from various countries that have successfully carried out peatland restoration efforts. The views obtained from this literature review study are an extension of existing programs that have been carried out before. 


\section{Results and Discussion}

\subsection{Peatland Rewetting}

Peatlands consist of a layer of soil formed from dead plants, which then create a new layer of soil. The process of forming peat soils is complicated and takes a long time. An ideal peatland, which is one type of wetland, is characterized by high-water content in the soil. However, if the peat soil is dry due to various factors, this creates the risk that the peat will be difficult to re-absorb water. Dry peat soils are like dry wood, which quickly dissolves in water flow and has a high risk of burning. Besides, hydrological conditions on peatlands associated with draining the land also cause oxidation of organic matter and emissions of carbon dioxide $\left(\mathrm{CO}_{2}\right)$, which is one of the greenhouse gases that cause global warming.

The existence of peat soils in the tropics presents its challenges because of the characteristics of the tropical climate, which can increase the risk of peat soil drying out. In addition, other factors such as massive exploitation and deforestation, land-use change, and climate change have contributed to the degradation of peatlands, which are already in locations with warm temperatures (tropical climate). Therefore, wetting peat or what is often called rewetting needs to be done to maintain the stability of the hydrological conditions of peatlands in tropical areas, which will then have a direct impact on the sustainability of the peatland ecosystem itself.

Rewetting peatlands, especially in areas within the form of peat-swamp forest, can be done by blocking waterways (canals) that are scattered in the peatland area (Murdiyarso, 2017). The channels that are blocked can be in the form of natural or artificial canals to raise the water level so that moisture and water content in the peatlands are maintained. This canal blocking also acts as a preventive measure in preventing peatland fires, especially during the dry season. Also, it is hoped that the blocking in the water-filled canals will be able to form new sources of life for organisms living in the peat ecosystem.

Rewetting on peatlands needs to be supported by the existence of supporting infrastructures, such as the construction of canal blocking and drilling wells. If canal blocks are used to raise the water level in peatlands, then bore wells can be used as water sources if peatland fire happens. Indonesia, as one of the locations for the distribution of tropical peatlands in the world, has also included rewetting in the critical program of peatland restoration. Peatland infrastructures used in Indonesia are carried out by involving many parties, including local communities, to increase the sense of belonging to the infrastructure (BRG Indonesia, 2020).

In Central Kalimantan, in particular, peatland areas face severe problems due to drainage or the construction of artificial canals in peat-swamp forest areas. This condition happened because of the mega rice project by the government in 1995-1996, which are thought to cause more rapid peatlands drought and an increased risk of forest fires (Borneo Nature Foundation, 2020). The increasing number of artificial canals in the peat-swamp forest area can add new risks, namely the possibility of illegal logging activities and the use of channels for the transportation of logs obtained from the local area. The creation of artificial canals with elevations below the peat soil causes water to flow into the channels, accelerating the flow of water from high to low elevations, thereby drying up areas of peat at higher elevations and sedimentation in the lower area. Other risks also arise from the materials used in constructing the canal bulkhead. Therefore, the use of techniques in rewetting peatlands is expected to consider the positive and negative impacts and use environmentally friendly materials so that the peat ecosystem can be returned to its normal condition. The canal system that works on tropical peatlands must adopt the principle of water distribution, not the opposite, precisely the drainage principles. 


\subsection{Canal Blocking using PVC Pipes and Peat Soil as Filling}

Canal blocking is one of the peatland rewetting infrastructures that has been widely implemented in various countries, such as Canada, China, Indonesia, European countries, and other countries. This peat wetting infrastructure is made with many kinds of material innovations and installation techniques according to the installation location. The use of canal blocking is closely related to the formation of a new artificial pond, which will form by itself after the canal is blocked. The canals that are scattered on these tropical peatlands are then isolated as water sources for the surrounding vegetation. Water sourced from this canal supports the revegetation program on peatlands.

The development of peatland rewetting innovations by blocking existing canals continues. Some of the materials used in the design of channel bulkheads include plank/wood, composite materials (compressed peat or soil), plastics, metal slabs, reinforced concrete, and canvass concrete. Apart from the use of materials, there are other supporting components needed, such as pumps, geotextile as a coating, spillway design, support frames, and construction reinforcement.

Based on a literature study of various peatland restoration efforts, especially peat rewetting techniques in various countries in the world, this study attempts to design innovative materials and techniques for rewetting peatland with existing canal blocking. The idea offered in this innovation is the use of PVC pipes as the primary material for canal bulkheads. PVC pipe with a diameter that adapts to the needs and width of the canal installed vertically and in the form of a row covering the entire canal section. Installation of this PVC pipe requires the support of a wooden frame to ensure the pipe is in the right position and is strong enough and not carried away by water flow. The design drawings of canal blocking made from PVC pipes and wooden frames are shown in Figures 2 and 3.

Figure 2. Canal Blocking Construction Frame

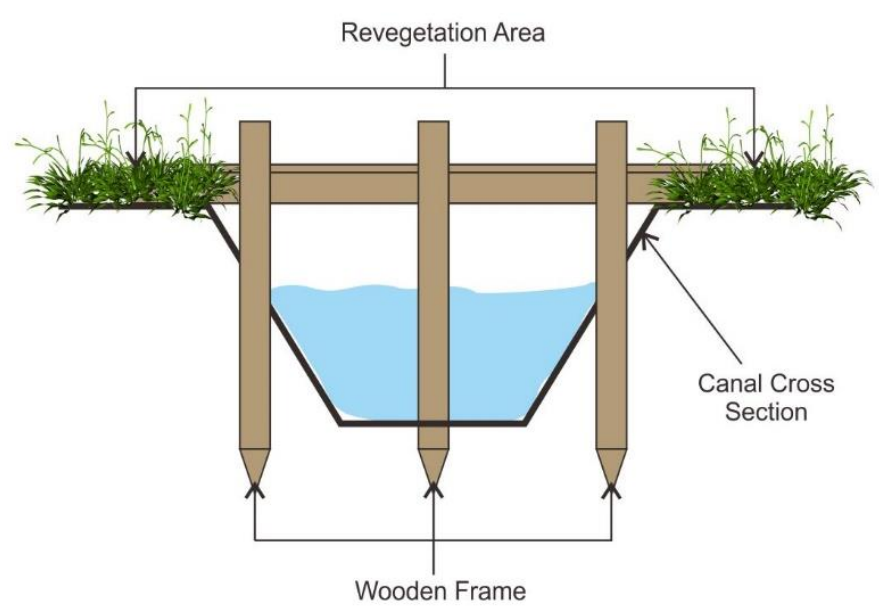

(Source: Author's Design, 2020) 


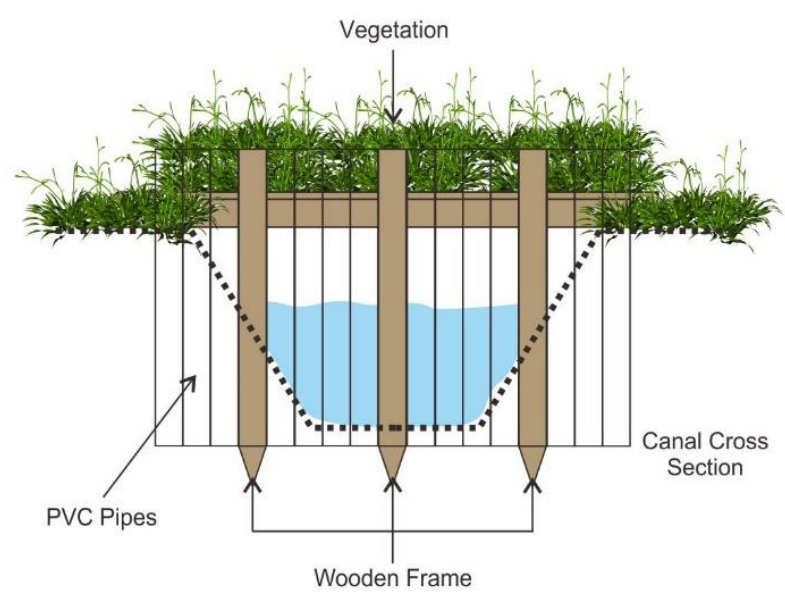

(Source: Author's Design, 2020)

The canal blocking design with PVC pipes material can be grouped into two categories according to needs and strength levels, namely single layer and multilayer canal bulkheads. A single layer canal blocking consists of two rows of PVC pipes construction reinforced with a wooden frame and has one layer of compacted peat soil in the middle, as shown in Figures 4 and 5. Multilayer canal blockings are constructions that have three or more rows of PVC pipes and a wooden support frame. In a multilayer canal blocking, there are two or more layers of compacted peat soil on each PVC pipe's layer boundary, as shown in Figure 6.

The canal blocking construction can also be equipped with a spillway to distribute water from the upstream to the downstream side of the channel if the water level has reached the threshold. The existence of this spillway is intended to maintain the resilience of the canal blocking construction if at any time there is a flood or excessive water runoff, which can cause damage to the canal blockings. The canal blocking design with spillway can be seen in Figures 4 and 6.

Figure 4. Canal Blocking Cross-Section Detail (Single Layer with Spillway)
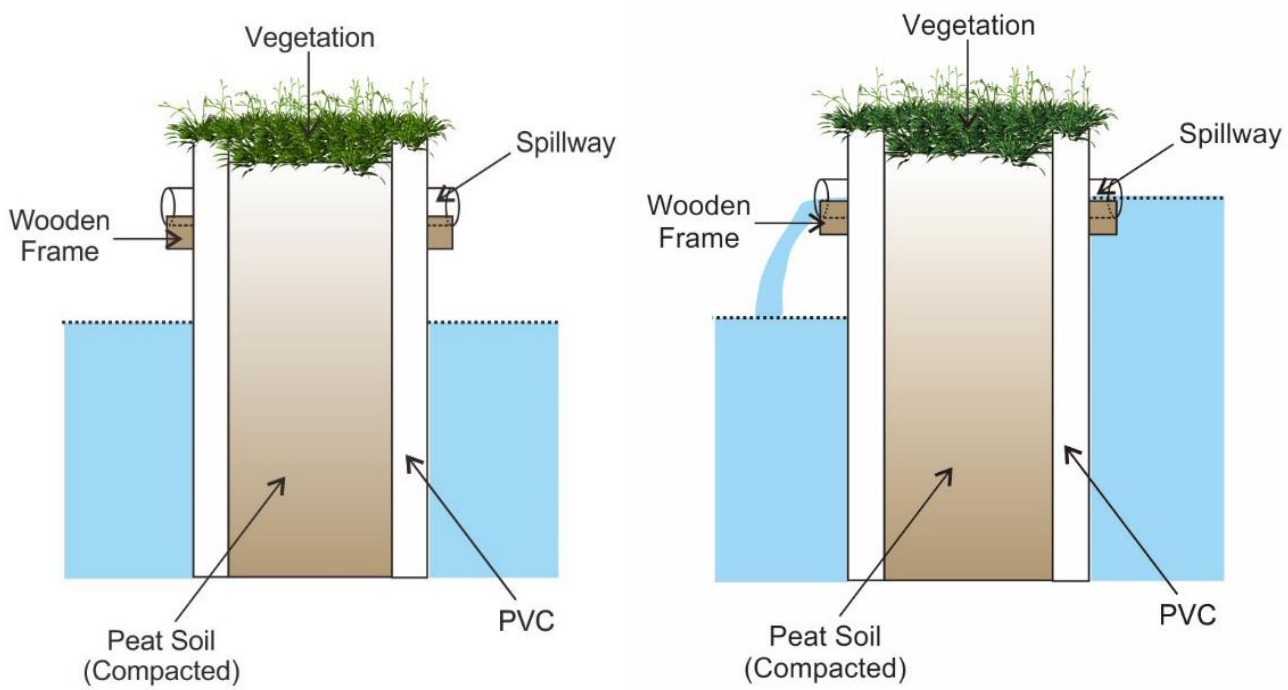

(Source: Author's Design, 2020) 
Figure 5. Canal Blocking Cross-Section Detail (Single Layer without Spillway)

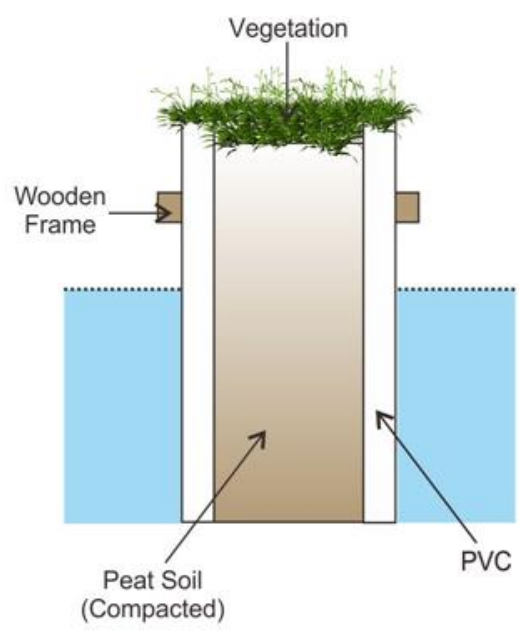

(Source: Author's Design, 2020)

Figure 6. Canal Blocking Cross-section Detail (Multilayer with Spillway)
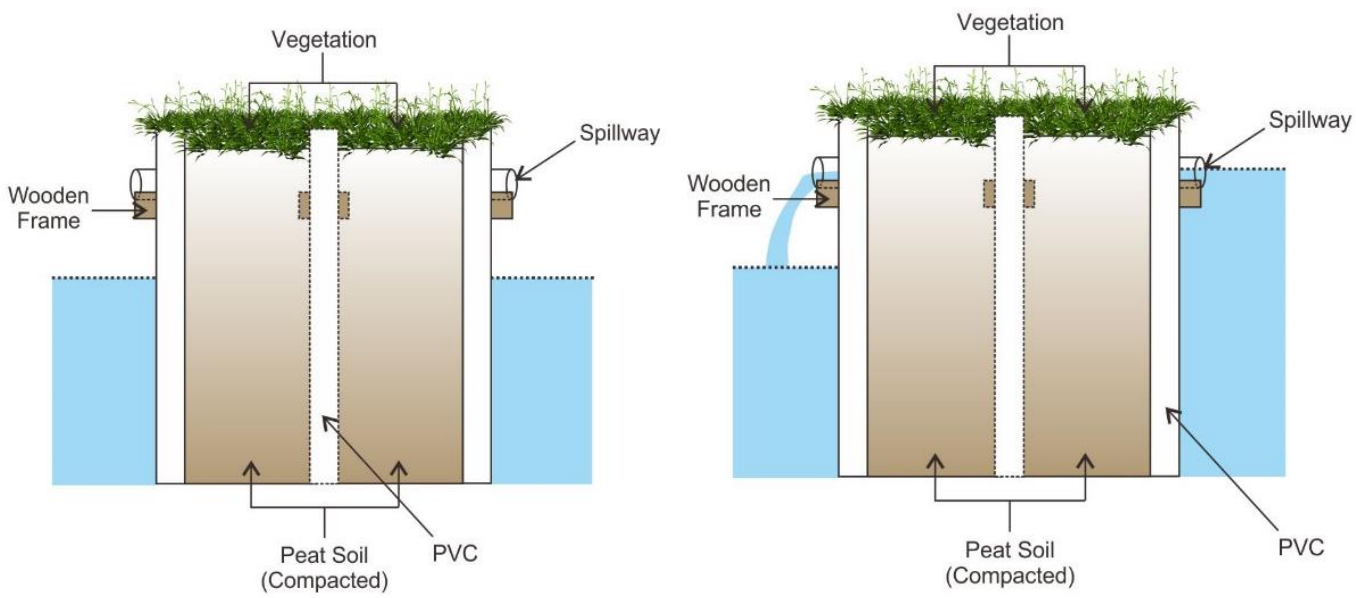

(Source: Author's Design, 2020)

The pipes that have been installed in a row are then filled with peat soil obtained from the local area. The purpose of filling the peat soil in the PVC pipe cavity is expected to be able to increase the strength and resistance of the pipe used as a canal blocking. Peat soil that is filled into the PVC pipe is maintained in a dense condition and is thoroughly filled to maximize the strength and resistance of the PVC pipe to water pressure. If a stronger bulkhead is needed, then a series of PVC pipes filled with peat soil can be installed in multilayers by giving space in the middle between layers and then filled with peat soil, which is also compacted. The top of the canal blocking can be used as a place for planting plants (Revegetation).

Figure 7 shows the top view of the single layer and multilayer canal blocking. In Figure 7 , it can be seen that vegetation planting can be done in the O-section and middle section of the canal blocking construction. These two sections are filled with dense/compacted peat soils to strengthen the canal blocking construction as well as providing revegetation areas. 
Figure 7. Canal Blocking Top View

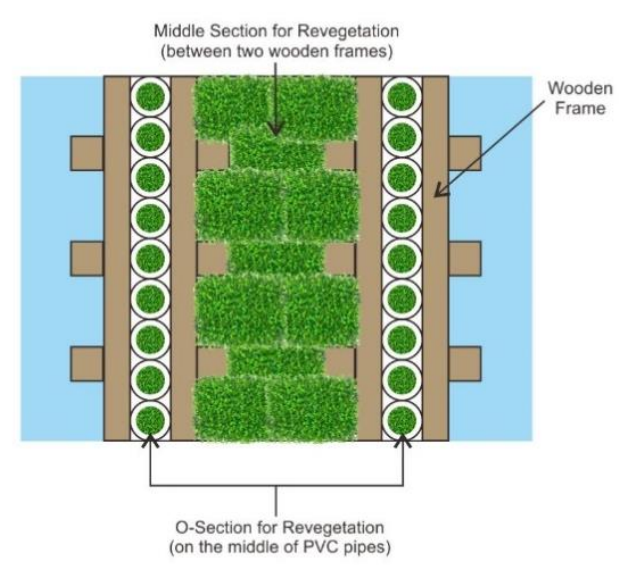

(Single Layer-Left)

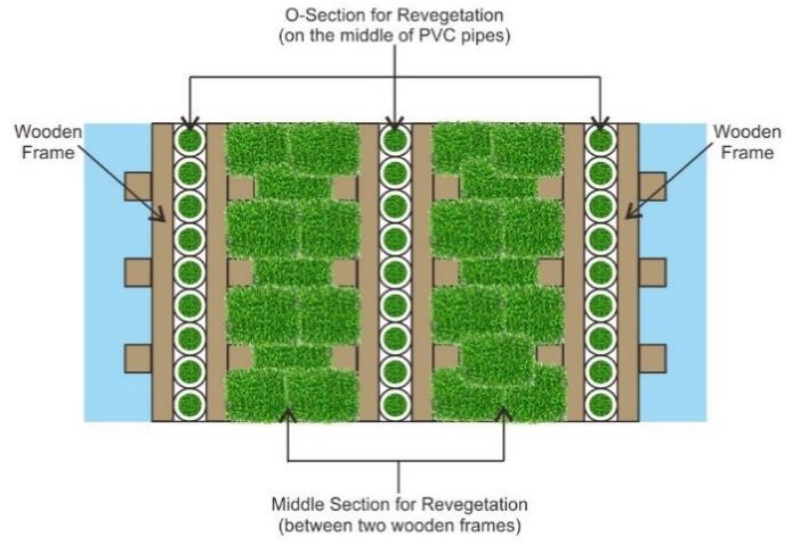

(Multilayer-Right)

(Source: Author's Design, 2020)

Apart from the construction of the canal blocking unit, it is also essential to consider the layout. Therefore, in this design, the canal blocking placement position is also made in the existing channel. Field conditions strongly influence construction placement. Elevation, flow direction, cross-section size/dimension, and flow rate in the channel are some factors that can affect the placement. In canal blocking installation with PVC pipes, a stronger multilayer canal bulkhead is placed at each of the ends of the channel because of water discharge differences at the junction between the channels. Meanwhile, in the central part, the bulkhead installed uses the same material, but with a lower number of layers and strength level compared to the channel blocking at the end of the channel.

Figure 8 is the layout planned for the canal bulkhead design. A1 and A2 are the locations for the placement of multilayer canal blocking or canal blockings with stronger construction. Meanwhile, B1, B2, and B3 are single layer canal blocking spots as supporting or an additional structure. The number of each channel blocking construction (single layer or multilayer) is adjusted to the length of the channel to be blocked.

Figure 8. Canal Blocking Layout

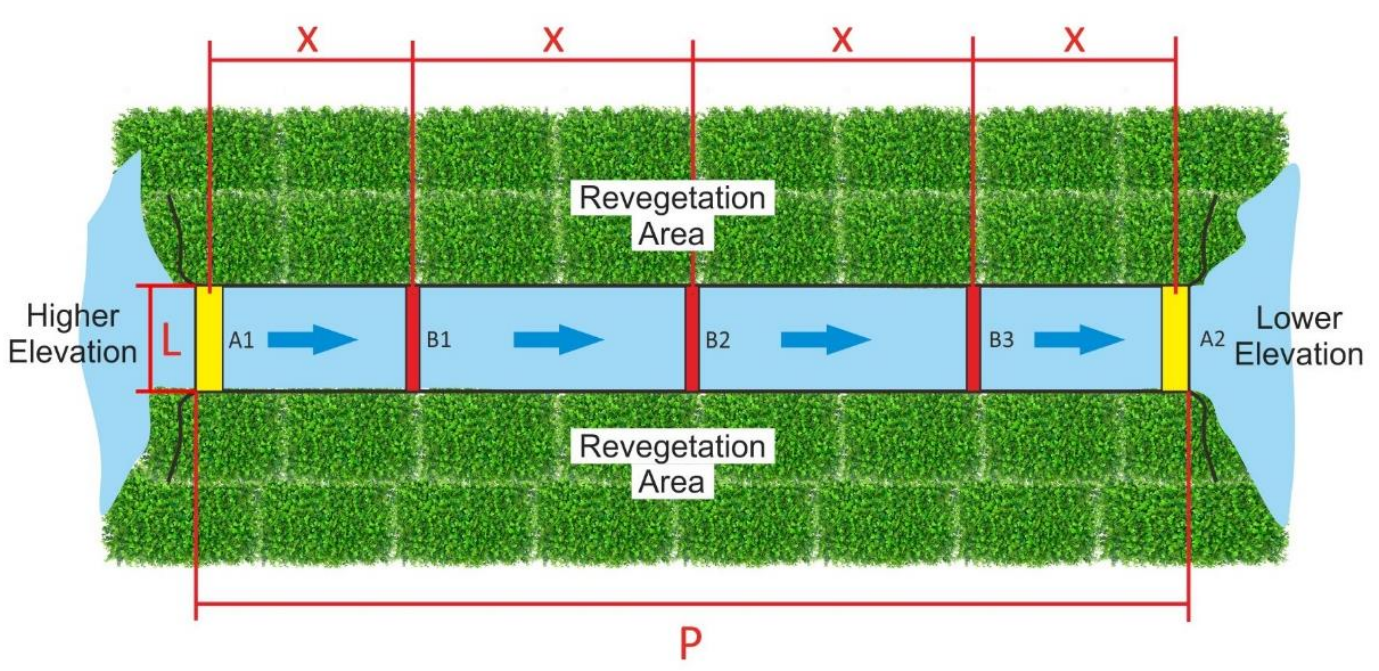

(Source: Author's Design, 2020) 
The area around the canal, especially the area along the blocked canal, can also be used as a place for vegetation (Revegetation) because it is very close to water sources. Therefore, this design is expected to be able to support two restoration programs at once, namely rewetting and Revegetation.

\subsection{Idea's Prospects and Challenges}

The canal blocking innovation using PVC pipe and dense peat soil as a filling is expected to add ideas regarding efforts to wet peatland with canal blocking. Although the use of PVC pipes cannot completely replace the function of wood, especially for the construction frame, it is hoped that the existence of PVC pipes can at least minimize the use of wood in the construction of canal blocking units. The use of PVC pipes is also expected to save costs for canal blocking construction because it can minimize the purchase of other building materials. When viewed from the aspect of mobilization, the use of PVC pipes, which tend to be lightweight and easy to carry, is expected to increase energy efficiency and the cost of building canal bulkheads as well. PVC pipe also has several other advantages, namely: durable, environmentally friendly, will not rust, resistant to sunlight, can be recycled, has low conductivity, easy installation, and maintenance-free.

The use of existing peat soil in the restoration site as a PVC pipe filling serves to increase the strength of the canal blocking construction without having to use other additional materials and can also be used as a medium for Revegetation in the peatland restoration program. Besides, the use of peat soil from the nearest area can decrease the mobilization cost as well.

The ideas offered in this study, of course, still require a lot of consideration and calculation related to dimensions, availability of tools and materials, as well as possible obstacles faced in the implementation. The future challenges that may be encountered in implementing this idea are the supply and mobility of PVC pipes to remote areas, considering that the peatlands that are being restored are generally located in relatively remote areas. There may be difficulties in installation and construction due to varying field conditions. However, despite all the prospects and challenges that may be faced in the future, it is hoped that this idea can continue to be developed to provide more choices of canal blocking innovations that can be applied according to the location conditions that require them.

\section{Conclusions and Recommendations}

\subsection{Conclusions}

Tropical peatlands are an important part of the sustainability of our earth. Many threats faced by peatlands as a result of human activities have reduced the function of the peatlands. The destruction of the peat has brought disaster to the earth and everything in it. Awareness of peatlands' importance and the threat has prompted many countries in the world to intensify efforts to improve the condition of peatlands and their ecosystems. One of the efforts to restore peatlands is to wet the peatlands. The discussion of peatlands was carried out to restore moisture to the peat soil and prevent fires due to the drying up of the peat soil. Efforts to rewet peatlands can be made by installing bulkheads in canals in peatlands.

The idea offered in rewetting peat with canal blocking is the use of PVC pipes as the primary material in the construction of canal blocking. This PVC pipe also uses a wooden frame as a supporting component, and the PVC pipe cavity is filled with high-density peat soil obtained from a local area. The purpose of this filling is to increase the strength and durability 
of the canal blocking structure and can be used as a small-scale revegetation area. Of course, this idea has two sides, namely prospects and challenges. This canal blocking innovation with PVC pipes is expected to increase resource efficiency and cost. However, there may also be challenges and difficulties in installing and supplying materials to areas where it is needed.

\subsection{Recommendations}

The idea in this study is an early stage that still requires further development and research to obtain a more detailed design related to size/dimensions, location placement, technical installation, construction strength level, cost and resource efficiency, and feasibility. Therefore, it is recommended that if there is a further study with a similar topic, it can be carried out to a more detailed and in-depth stage to obtain a clearer picture regarding the idea and possible implementation. 


\section{BIBLIOGRAPHY}

\section{Journal}

Rieley J. and Page S. 2016. Tropical Peatland of the World. In: Osaki M., Tsuji N. (eds) Tropical Peatland Ecosystems. Tokyo: Springer. Accessed on October 11st. doi: https://doi.org/10.1007/978-4-431-55681-7_1.

Dohong A., Aziz A A., and Dargusch P. 2017. A Review of The Drivers of Tropical Peatland Degradation in South-East Asia. Land Use Policy 69:349-360. Accessed on October 11st. doi: https://doi.org/10.1016/j.landusepol.2017.09.035.

Leng L Y., Ahmed O H., and Jalloh M B. 2019. Brief Review on Climate Change and Tropical Peatlands. Geoscience Frontiers 10 (2):373-380. Accessed on October 11st. doi: https://doi.org/10.1016/j.gsf.2017.12.018.

Dargie, Lawson, Rayden, et al. 2019. Congo Basin peatlands: threats and conservation priorities. Mitigation and Adaptation Strategies for Global Change 24:669-686. Accessed on October 13rd. doi: https://doi.org/10.1007/s11027-017-9774-8.

\section{Website}

Christopher Craft, in Creating and Restoring Wetlands, 2016. Accessed on October 11st. https://www.sciencedirect.com/topics/earth-and-planetary-sciences/peatland.

UN Environment. 2019. "Peatlands Stored Twice as Much Carbon as All the World's Forests." Last changed Feb $1^{\text {st }}$, 2019. Accessed on October 11st. https://www.unenvironment.org/news-and-stories/story/peatlands-store-twice-muchcarbon-all-worlds-forests.

Government of Canada, 2020. "Peatland Fires and Carbon Emissions." Last changed July $15^{\text {th }}$, 2020. Accessed on October 11st. https://www.nrcan.gc.ca/climate-change/impactsadaptations/climate-change-impacts-forests/forest-carbon/peatland-fires-carbonemissions/13103.

National Geographic, 2011. "Tropics." Last changed Jan 21 ${ }^{\text {st }}, 2011$. Accessed on October 11st. https://www.nationalgeographic.org/encyclopedia/tropics.

Pantau Gambut, 2020. "Langkah-langkah Restorasi Gambut (Peat Restoration Steps)." Accessed on October 11st. https://www.pantaugambut.id/pelajari/pemulihkan-lahangambut/langkahlangkah-restorasi-gambut.

Quinty, F., M.-C. LeBlanc and L. Rochefort. 2020. Peatland Restoration Guide - Site Preparation and Rewetting. PERG, CSPMA and APTHQ. Québec, Québec. Accessed on October 12nd. https://tourbehorticole.com/wpcontent/uploads/2020/10/Guide_4.2_Site_Preparation_and_Rewetting_ANG.pdf.

Food and Agriculture Organization of the United Nations. 2015. Peatland Restoration in China. Mitigation of Climate Change in Agriculture (MICCA) Programme of FAO. Accessed on October 12nd. http://www.fao.org/3/ca4044en/ca4044en.pdf.

Cris, R. Buckmaster, S. Bain, C. Reed, M. (Eds). 2014. Global Peatland Restoration demonstrating SUCCESS. IUCN UK National Committee Peatland Programme, Edinburgh. Accessed on October 12nd. https://www.iucn-ukpeatlandprogramme.org/sites/default/files/201907/IUCNGlobalSuccessApril2014_0.pdf. 
Pantau Gambut, 2020. “Apa itu Restorasi Gambut (What is Peat Restoration).” Accessed on October 12nd. https://www.pantaugambut.id/pelajari/pemulihkan-lahan-gambut/apaitu-restorasi-gambut.

Mongabay, 2020. "Empat Tahun BRG: Daya dan Upaya Pulihkan Gambut Negeri (Four Years of BRG: Power and Efforts to Restore National Peatlands)." Last changed January $28^{\text {th }}$, 2020. Accessed on October 12nd. https://www.mongabay.co.id/2020/01/28/empat-tahun-brg-daya-dan-upaya-pulihkangambut-negeri/.

Hans Joosten, Marja-Liisa Tapio-Biström \& Susanna Tol (eds.). 2012. Peatlands - Guidance for Climate Change Mitigation through Conservation, Rehabilitation and Sustainable Use. Mitigation of Climate Change in Agriculture Series 5, Rome. Accessed on October 12nd. http://www.fao.org/3/a-an762e.pdf.

Murdiyarso D., Kurnianto S., Hergoualc'h K., Sasmito S., and Hanggara B. 2017. Pembasahan kembali lahan gambut. Sains dibalik gambut. Accessed on October 13rd. https://www.cifor.org/publications/pdf_files/factsheet/6442-factsheet.pdf.

Badan Restorasi Gambut (BRG) Indonesia. 2020. "Pembasahan Lahan Gambut Lebih Gencar Untuk Hadapi Kemarau Tahun Ini (Wetting of Peatlands More Intensively to Face the Dry Season This Year)." Accessed on October 13rd. https://brg.go.id/pembasahanlahan-gambut-lebih-gencar-untuk-hadapi-kemarau-tahun-ini/.

Borneo Nature Foundation. 2020. "Canal Blocking." Accessed on October 13rd. http://www.borneonaturefoundation.org/en/saving-the-rainforest/canal-blocking/. 